\title{
5. Problematyka bezpieczeństwa w gospodarce magazynowej
}

Monika Zajączkowska*

\subsection{Wstęp}

Celem rozdziału jest usystematyzowanie wiedzy z zakresu bezpieczeństwa w gospodarce magazynowej i zwrócenie uwagi na problem bezpieczeństwa w tym obszarze. Materiał oparto na źródłach książkowych i internetowych. Chcąc ując omawiana problematykę $w$ interesujacy i przystępny sposób, autorka zawarła w treści subiektywne refleksje, wynikające $z$ doświadczenia zawodowego w obszarze gospodarki magazynowej.

Problematykę bezpieczeństwa ( $w$ oparciu o magazyn tradycyjny) omówiono, biorąc pod uwagę pięć następujących czynników:

- osoby znajdujące się na obszarze magazynu,

- organizacja hali magazynowej,

- składowanie zapasów,

- pojazdy używane w gospodarce magazynowej,

- czas jako czynnik wpływający na bezpieczeństwo ludzi i zapasów.

\subsection{Osoby znajdujące się na obszarze magazynu}

Każda osoba przebywająca w strefie magazynowej, bez względu na to, czy jest pracownikiem, czy znajduje się tam tymczasowo, powinna przede wszystkim mieć świadomość zagrożeń wynikających z charakteru miejsca, w którym przebywa. Świadomość ta powinna zostać ukształtowana przez prawidłowo przeprowadzone szkolenie z zakre-

* Lic. Monika Zajączkowska - Katedra Logistyki, Wydział Zarządzania Uniwersytetu Łódzkiego, ul. Matejki 22/26, 90-237 Łódź. 
su BHP. Zdaniem autorki, wspomniane szkolenia w niewystarczający sposób omawiaja temat potencjalnych zagrożeń, niewielką wagę przywiązuje się także do analizy zależności przyczynowo-skutkowych. Jako przykład można tu podać kwestię konieczności noszenia kasku - nie tłumaczy się, przed jakimi zagrożeniami chroni on zdrowie i życie pracownika. Gdyby nie pomijano tego istotnego tematu, wykorzystywanie hełmu w sytuacji ekstremalnej z pewnością zastapiłoby działanie prewencyjne. Niedostatecznie także działa się na wyobraźnię pracowników, niezależnie od pełnionej przez nich funkcji. Według autorki, gdyby szkolenia BHP i kursy na operatorów wózków widłowych wzbogacono o studia przypadków i prezentacje materiałów wideo z wypadków w magazynach, świadomość zagrożeń bezpieczeństwa byłaby znacznie większa.

Świadomość bezpieczeństwa ma - oprócz tego zwiazanego z ludźmi - także drugi wymiar, odnoszący się do bezpieczeństwa składowania towaru. Wiele wskazuje na to, iż również w tym względzie świadomość pracowników jest niska. Nie wiedzą oni, jak powinno się składować zapasy i jak swoja praca moga wpłynąc na bezpieczeństwo składowanego towaru. Przykłady z terenu naszego kraju dowodza, że wynika to często z braku kompetencji kadry kierowniczej, nieposiadajacej dostatecznej wiedzy, którą mogłaby przekazać swoim pracownikom. Są zakłady pracy, w których nie istnieje dział BHP, nie ma osoby odpowiedzialnej za bezpieczeństwo, nie prowadzi się szkoleń i nie ma żadnych ustalonych zasad, procedur i standardów.

Drugim elementem związanym z ludźmi jest odzież i obuwie safety. Na taki strój składaja się:

- kask (hełm przemysłowy),

- kamizelka odblaskowa,

- buty safety,

- rękawice ochronne,

- ubiór roboczy.

Operatorzy wózków widłowych są w momencie zagrożenia w o tyle "lepszej sytuacji", że ponieważ są w pojeździe, chroni ich rama bezpieczeństwa, klatka bezpieczeństwa i maszt wraz z karetką z przodu wózka (rys. 8, elementy oznaczone litera a).

Wózek widłowy powinien być wyposażony w pasy bezpieczeństwa. Ta forma zabezpieczenia spełnia swoja szczególną rolę, gdy pojazd utraci środek ciężkości i przewróci się. Pasy chronia wówczas przed sytuacja, w której operator wypadłby pierwszy, a wózek upadłby na niego. Niestety, takie wypadki nie należą do rzadkości. 


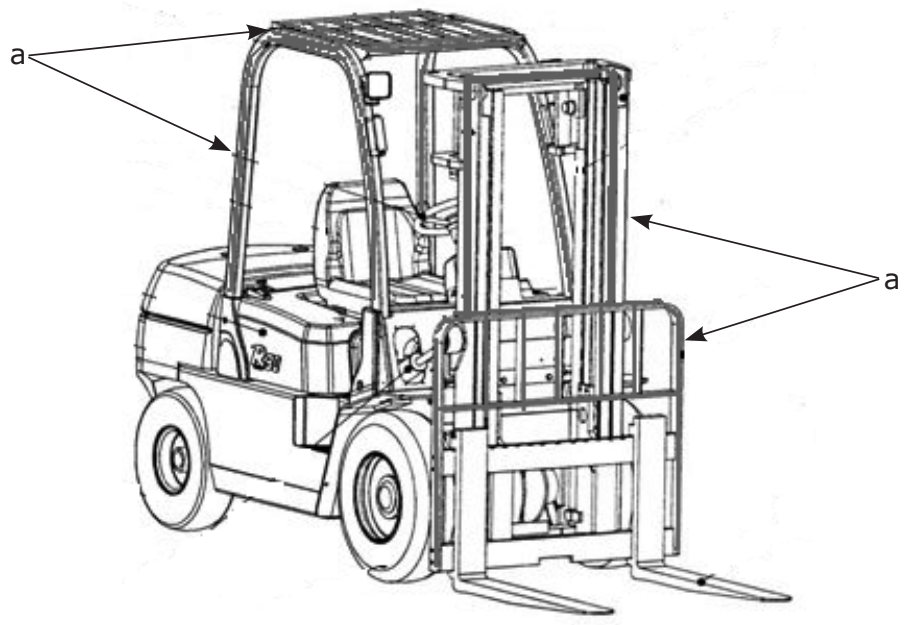

Rysunek 8. Elementy wózka widłowego ochraniające operatora (ozn. a) Źródło: opracowanie własne

Należy w tym miejscu zaznaczyć, iż nie każdy rodzaj wózka widłowego wyposażony jest w klatkę bezpieczeństwa. Takim przykładem są wózki boczne.

W sytuacji zagrożenia operator wózka widłowego nie ma osłonionej głowy. Podczas pracy powinien mieć założoną kamizelkę odblaskową, dzięki której byłby bardziej widoczny dla pozostałych osób. Jest to szczególnie ważne, gdy wózki szybko się przemieszczają oraz gdy operatorzy nie maja w zwyczaju lub przejeżdżając zapomną ostrzec innych sygnałem dźwiękowym. Pracownik pieszy wchodzący na teren magazynu także musi bardzo dobrze widzieć operatorów wózków.

Pracę obsługiwanego wózka widłowego skutecznie tłumią odgłosy pozostałych pojazdów przemieszczających się na terenie magazynu. Wózki widłowe wysokiego składowania jeżdżą szczególnie cicho, dlatego jadąc szybko na bocznym wózku, w chwili nieuwagi można zderzyć się z innym pojazdem.

Najbardziej narażona grupa pracowników sa ci nieobsługujący wyposażonego w klatkę bezpieczeństwa wózka widłowego.

Zagrożenia moga płynąć zarówno ze strony przejeżdżających wózków widłowych, jak i wyposażenia magazynu (np. metalowych klatek na składaki z towarem, tzw. koszy). Dlatego też niezwykle ważne jest używanie obuwia safety. Oryginalne buty safety posiadaja metalowe wzmocnienie na czubku, które wytrzymuje nawet przejechanie po nim wózka widłowego. Pierwszym elementem, który chroni pracowników 
przy kontakcie z wózkiem są właśnie buty safety. Znajdziemy przykłady wielu zakładów w Polsce, w których nie wszyscy pracownicy otrzymują jakiekolwiek obuwie ochronne (nawet tzw. noski). Problem ten dotyka najczęściej pracowników traktowanych jako tymczasowi, zatrudnianych niejednokrotnie na umowę zlecenie.

Buty do użytku w pracy. Safety shoes chronia przed uszkodzeniami mechanicznymi i chemicznymi. Obuwie stosowane w zakładach pracy podlega dyrektywie 89/686/EWG i musi spełniać jej wymogi. Dodatkowymi aktami normatywnymi są obowiązujace w Polsce normy:

- PN-EN 345 - obuwie bezpieczne (safety) do użytku w pracy,

- PN-EN 346 - obuwie ochronne (protective) do użytku w pracy,

- PN-EN 347 - obuwie zawodowe (occupational) do użytku w pracy,

- PN-77/0-91030 - obuwie wyjściowe, robocze i domowe.

Buty safety (PN-EN 345) posiadaja podnosek stalowy albo - ze względu na połączenie lekkości i wytrzymałości - podnosek kompozytowy (tj. taki, w którym komponentem konstrukcyjnym sa silne włókna). Obuwie safety powinno chronić palce stopy przed uderzeniem o energii $200 \mathrm{~J}$ (przypomnijmy, że: $1 \mathrm{~J}=1 \mathrm{~N} \times \mathrm{m} ; 1 \mathrm{~J}=1 \mathrm{~kg} \times \mathrm{m}^{2} / 1 \mathrm{~s}^{2}$ ).

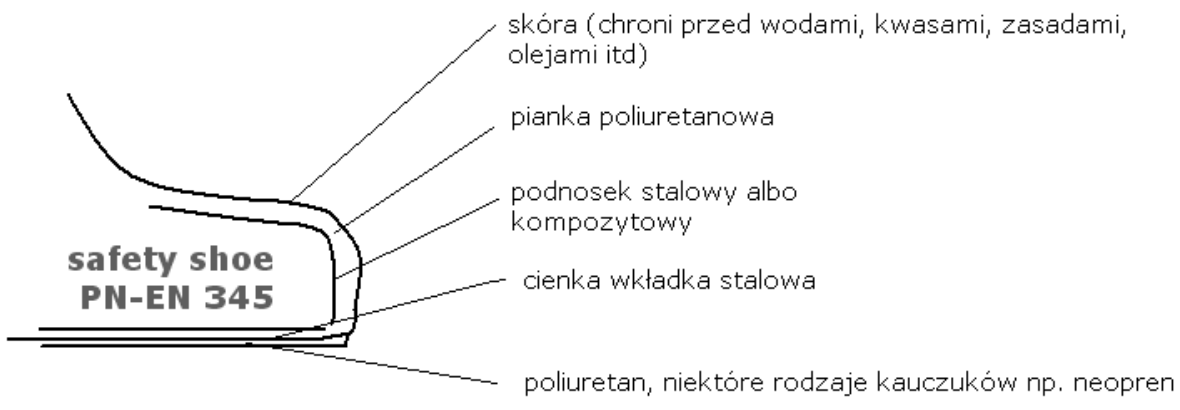

Rysunek 9. Budowa buta safety

Źródło: opracowanie własne

Przed przekłuciem podeszwę buta chroni cienka stalowa wkładka, wytrzymujacca przekłucie o sile $1100 \mathrm{~N}^{1}$ (przypomnijmy, że: $1 \mathrm{~N}=1 \mathrm{~kg}$ $\times \mathrm{m} / 1 \mathrm{~s}^{2}$ ). Zewnętrzna część buta pokrywa skóra, której zadaniem jest ochrona stopy przed działaniem wody, kwasów, zasad, olejów, smarów, rozpuszczalników organicznych, tłuszczów i środków ochrony roślin. Przestrzeń pomiędzy skórą a podnoskiem wypełnia pianka poliuretano-

\footnotetext{
${ }^{1}$ www.higiena-pracy.net/?obuwie,14 [z dn. 11.10.2012].
} 
wa. Poliuretan ${ }^{2}$ stosowany jest także w podeszwie buta. Innym materiałem, którego także używa się do produkcji podeszw obuwia safety, są niektóre rodzaje kauczuków, np. neopren³ (rys. 9).

Dodatkową cechą butów ochronnych może być ich elektroizolacyjność. $Z$ reguły $w$ butach używanych $w$ gospodarce magazynowej mieści się ona w przedziale $220 \mathrm{~V}-250 \mathrm{~V}$. Produkuje się też buty specjalistyczne, używane np. przez elektryków i elektromonterów, których parametry elektroizolacyjne są znacznie wyższe, sięgające nawet do $11000 \mathrm{~V}$.

PN-EN 346 - obuwie ochronne (protective) do użytku w pracy. Oznaczane litera "P" od angielskiego słowa protective. Chroni palce stopy przed uderzeniem $100 \mathrm{~J}$.

PN-EN 347 - obuwie zawodowe (occupational) do użytku w pracy. Oznaczane litera " $\mathrm{O}$ " od angielskiego słowa occupational. Ten rodzaj obuwia nie musi posiadać podnoska.

Kamizelka odblaskowa. Drugim elementem, który obowiązkowo powinien mieć na sobie każdy pracujący na terenie magazynu jest kamizelka odblaskowa. Autorka z własnego doświadczenia wie, że jeśli kierownik chce "przyłapać" swoich podwładnych na "nic nierobieniu”, to nie zakłada kamizelki. Wystarczy bowiem ten element stroju, by pracownicy widzieli taką osobę ze znacznej odległości (w magazynie z np. 15 tys. miejsc paletowych bardzo wyraźnie widać osobę ubraną w kamizelkę odblaskowa, nawet gdy przebywa ona na drugim końcu hali). Operator wózka widłowego musi być w czasie pracy skupiony na wielu czynnościach: wyjmowaniu i wkładaniu towaru, zachowaniu przy tym odpowiedniego balansu, skupić się na pozycji wózka przy przewożeniu towaru, zwracać uwagę na przeszkody, ruch pozostałych wózków, "paleciaków" i materiał pozostawiony wokół miejsca pracy. Jeżeli pojedyncza osoba porusza się po magazynie, to mając na sobie kamizelkę odblaskowa, w najprostszy sposób umożliwia operatorowi wózka dostrzeżenie jej z bezpiecznej odległości, nawet podczas wykonywania wielu różnych czynności. Z perspektywy osoby pieszej takie zachowanie zwiększa jej bezpieczeństwo.

Istotna sprawą, na która także należy zwrócić uwagę, jest kolor stosowanych kamizelek. $Z$ reguły występuja one $w$ dwóch barwach: jaskrawozielonej i jaskrawopomarańczowej. Jeżeli zatem regały sa w kolorze pomarańczowym, to czy dobrym pomysłem jest używanie kami-

\footnotetext{
2 Poliuretan - polimer powstający na skutek polimeryzacji wielofunkcyjnych izocyjanianów do amin i alkoholi.

${ }^{3}$ Neopren - kauczuk syntetyczny, który ma większą odporność na oleje i inne rozpuszczalniki organiczne, wolniej się starzeje, ma własności samogaszące.
} 
zelek w tym samym kolorze? Rola, jaką ma spełniać kamizelka, jest wówczas niespełniona albo mocno ograniczona. Należy wybierać kamizelki w kolorze, który nie występuje na terenie magazynu.

Kask przemysłowy, nazywany także hełmem przemysłowym. Zadaniem kasku przemysłowego jest ochrona przed urazami czaszki, mózgu i karku, które moga powodować obiekty spadajace lub uderzajace ${ }^{4}$.

Powszechnie znaną normą dotycząca kasków jest norma PN-EN 397 (zdolność amortyzacji 49 j5). Kaski, które ja spełniaja nazywane są hełmami przemysłowymi ochronnymi.

Dodatkowym wymogiem normy PN-EN 397 jest elektroizolacyjność. Test na nia polega na zanurzeniu hełmu na 24 h w słonej wodzie ( $3 \mathrm{~g}$ soli na 1 I wody) i umieszczeniu wewnattrz oraz na zewnatrz hełmu elektrod podłączonych do źródła prądu przemiennego (rys. 10). Maksymalne dopuszczalne natężenie przepływającego prądu zostało określone na 1,2 mA w czasie $30 \mathrm{~s}$ przy napięciu $1200 \mathrm{~V}^{6}$.

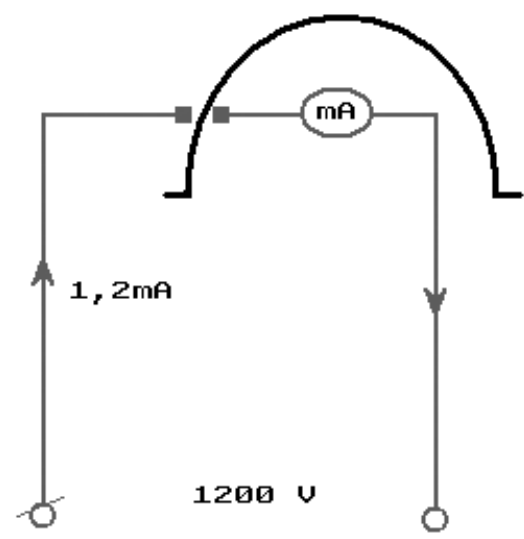

Rysunek 10. Schemat testu na elektroizolacyjność hełmu Źródło: opracowanie własne

Druga norma, określająca nieco niższe parametry, jest PN-EN 812 (zdolność amortyzacji 12 J7). Hełmy, które ja spełniaja, nazywane sa hełmami przemysłowymi lekkimi.

${ }^{4}$ www.narzedziownie.pl/?t $=k \& i=209 \& n=51216[z \mathrm{dn} .11 \cdot 10.2012]$.

${ }^{5}$ www.p4s.pl/index.php?option $=$ com_content\&view $=$ article\&id $=106 \&$ Itemid $=113$ [z dn. 29.11.2012].

6 Tamże.

7 Tamże. 
Norma PN-EN 14052 zawiera obowiązkowe wymagania, mające zastosowanie do wszystkich hełmów przemysłowych o podwyższonych parametrach ochronnych oraz wymagania dodatkowe, które mają zastosowanie, gdy zostaną specjalnie wskazane przed producenta hełmu. Ochrona według normy PN-EN 14052 jest trzykrotnie wyższa od tej według PN-EN 397.

Przykładowy hełm ${ }^{8}$, który spełnia normę PN-EN 14052 zbudowany jest $z$ :

1) HDPE (high density polyethylene - polietylen o dużej gęstości) - termoplastiku. Jest to materiał dielektryczny, którego temperatura topnienia wynosi $125^{\circ} \mathrm{C}$. Ma zwiększoną wytrzymałość mechaniczna,

2) polistyrenu (EPS - expanded polystyrene). Polistyren wykorzystuje się przy produkcji pudełek na płyty CD czy szczoteczek do zębów. W tym przypadku mamy jednak do czynienia z polistyrenem typu expanded, czyli spienionym. To nic innego jak styropian, czyli kolejny element hełmu, który jest dielektrykiem (izolatorem), 3) wyściółki z mikrofibry (mikrowłókna).

Koszt takiego hełmu to 126-127 zł․ Analizując ten najważniejszy element stroju ochronnego, nie sposób przejść obojętnie obok kwestii bagatelizowania jego znaczenia. Wielu bowiem kojarzy się on z pracami budowlanymi, a nie „bezpieczną praca pod dachem”, gdzie przecież „nic nie ma prawa spaść na głowę”. Powszechnie jednak wiadomo, że "przykład idzie z góry”, czego wyrazem jest niechętne używanie kasków przez pracowników magazynu jednej z firm. Jak się okazało, powodem takiego zachowania był fakt, że kierownicy, menadżerowie i dyrektorzy, przychodząc na teren magazynu, każdorazowo nie zakładali ochronnych nakryć głowy. To z kolei przekładało się na lekceważące podejście pracowników niższego szczebla do kwestii bezpieczeństwa w miejscu pracy.

\subsection{Organizacja hali magazynowej}

Hala magazynowa powinna być zorganizowana nie tylko pod katem logistycznym (organizacja pracy), lecz także pod względem bezpieczeństwa. Znaczenie maja tutaj:

- wyznaczone linie (line marking),

- drożność ciągów komunikacyjnych,

${ }^{8}$ www.glovex.com.pl/Store/index.php?p721,kask-ochronny-jsp-mk8-pokretlo [z dn. 29.11.2012].

${ }^{9}$ Cena na dzień 5 maja 2012 r. 
- regały,

- ochrona stanowisk pracy,

- lusterka,

- barierki.

Linie. Przemysłowe oznakowanie poziome. Rozporządzenie Ministra Pracy i Polityki Socjalnej z dnia 26 września 1997 r. w sprawie ogólnych przepisów bezpieczeństwa i higieny pracy (tekst jedn.: Dz.U. z 2003 r., nr 169, poz. 1650 z późn. zm.) nakazuje pracodawcy oznakować, zgodnie z odpowiednimi przepisami, drogi komunikacyjne i transportowe oraz drogi dla pieszych na terenie zakładu pracy. Podobne wymagania dotyczą także oznakowania innych miejsc, np. pól odkładczych, miejsc na gaśnice, stałych miejsc pojemników na odpady na terenie magazynu towarowego ${ }^{10}$.

Odpowiednie rozmieszczenie linii na terenie magazynu wynikać może z przeprowadzonej i kontynuowanej metody " $5 \mathrm{~S}^{\prime}$. Z doświadczenia autorki wynika, że są w Polsce zakłady pracy zajmujące się magazynowaniem i transportem towaru na obszarze całego kraju i zatrudniajace powyżej 100 pracowników, w których kadra kierownicza nigdy nie słyszała 0 "5S". Linie w magazynie powinny wyznaczać trasy dla pieszych, trasy przejazdu wózków widłowych i miejsca składowania towaru, pustych palet, uszkodzonych elementów inne niż regały. Takie oznakowanie organizowane jest na zasadzie ruchu drogowego. Trasy dla pieszych wyznaczane sa na ogół od wejścia na teren magazynu do biura i do drzwi ewakuacyjnych (ustala się np. 2-3 najbardziej optymalne i bezpieczne ścieżki). Nie wyznacza się tras między regałami, ponieważ obszar ten zarezerwowany jest wyłącznie dla wózków widłowych. Przestrzeń między regałami bywa często tak wąska, że oprócz wózka zmieści się tam "tabliczka czekolady" (ok. $20 \mathrm{~cm}$ przestrzeni, która pozostaje po wjechaniu pojazdu między regały). Praktyka pokazuje, że piesi niejednokrotnie poruszaja się w miejscach dla nich nieprzeznaczonych, np. celem sprawdzenia, czy towar faktycznie znajduje w danej lokacji - jest to jednak zachowanie niosące ze sobą ryzyko wypadku. Inaczej rzecz się ma w halach produkcyjnych, gdzie na całych ich powierzchniach wyznaczone są ścieżki dla pieszych, którzy zawsze maja pierwszeństwo.

Wyznaczanie linii, czyli line marking zawsze należy przeprowadzać w sposób logiczny. Sprowadza się to do wykonania odpowiedniego projektu, uwzględniajaccego położenie regałów, charakter wykonywanych prac, ruchy wózków i rodzaj przewożonego towaru. Planuje się

${ }^{10}$ www.bhp.abc.com.pl/czytaj/-/artykul/jak-oznakowac-w-zakladzie-pracy-pola-odkladcze-miejsce-na-gasnice-stale-miejsca-pojemnikow-na-odpady-itp [z dn. 11.10.2012]. 
też, gdzie będą znajdywały się pola odkładcze i uwzględnia ruch pieszych. Poprawne wyznaczenie linii ma wpływ na drożność ciagów komunikacyjnych. Niedopuszczalne jest bowiem stawianie towaru w przypadkowych miejscach, co mogłoby zagrozić operującym wózkom czy uniemożliwić ich swobodny przejazd.

Reasumując, na terenie magazynu nic nie stoi przypadkowo, wszystko ma swoje wyznaczone miejsce. Metody wykonywania linii:

- naklejane,

- malowane cienkowarstwowe,

- malowane grubowarstwowe,

- termoplastyczne - oznakowanie termoplastyczne wykonuje się przy użyciu sproszkowanej masy chemoutwardzalnej, którą podgrzewa się do odpowiedniej temperatury (ok. $190-210{ }^{\circ} \mathrm{C}$ ), a następnie aplikuje za pomoca samojezdnych lub ręcznych maszyn do układania mas termoplastycznych. Oznakowanie takie wyróżnia się wysoką odpornością na ścieranie, warunki atmosferyczne, działanie promieni słonecznych i użycie solanki ${ }^{11}$,

- permanentne - tego typu oznakowanie uzyskuje się przez usunięcie ok. 200 mikronów górnej warstwy posadzki betonowej przy pomocy śrutownicy wyposażonej w specjalna głowicę. Powstałą w ten sposób bruzdę o szerokości min. $10 \mathrm{~cm}$ wypełnia się chemoutwardzalną farbą na bazie żywic epoksydowych. Wypełnianie odbywa się pod wysokim ciśnieniem metodą airless. Główną zaletą powstałego w ten sposób oznakowania jest maksymalne zespolenie z podłożem oraz odporność na zerwanie przez przesuwane po posadzce palety, metalowe kosze itp. ${ }^{12}$

Regały. Kolejną istotną częścią magazynu są regały. Na rynku występuje duże zróżnicowanie jakości ich wykonania. Stalowe regały szynowe kosztuja więcej i - ze względu na wyższe dopuszczalne obciążenie - wymagaja podłoża o zwiększonej wytrzymałości. Spotkać można też takie, które wykonano z cienkiej blachy. Regały są bardzo newralgiczna częścią magazynu, narażoną na uszkodzenia przez wózki widłowe. Powinny one spełniać normy europejskie i posiadać stosowne certyfikaty.

Kiedyś obowiązywał FEM (organizacja o zasięgu europejskim, skupiająca producentów wyposażenia magazynowego), był on jednak tylko zaleceniem branżowym. Obecnie FEM zamieniono na następujące normy:

${ }^{11}$ www. wimark.pl/index.php?go=uslugi\&idk $=5$ [z dn. 11.10.2012] .

${ }^{12}$ www.malowanielinii.pl/liniespecjalne.php [z dn. 11.10.2012]. 
- PN-EN 15512,

- PN-EN 15620,

- PN-EN 15629,

- PN-EN 15635.

Dwie pierwsze i jednocześnie najważniejsze normy określaja zasady projektowania strukturalnego, tolerancje, odkształcenia i luzy. Normy te precyzuja użytkowanie regałów, ich budowę, projektowanie i badania techniczne. Dostawca wyposażenia magazynowego powinien przekazać odbiorcy deklarację zgodności swoich produktów z powyższymi normami.

Zaleca się, by raz w tygodniu stan regałów sprawdził wyznaczony pracownik magazynu, raz w miesiącu - kierownik magazynu, a minimum raz na 12 miesięcy - zewnętrzna firma, zajmująca się przeglądami.

Składowany towar powinien zajmować jedną lokację w magazynie. Takie założenie stosuje się ze względu na optymalizację jakości składowanego zapasu i bezpieczeństwo składowania (zarówno dla zapasów, jak i pracowników magazynu). Każdy regał posiada maksymalne obciażenie, którego nie wolno przekraczać w miejscach do tego nieprzeznaczonych, towarami niestandardowymi, ze zbyt wysoką masa własna.

Producenci oznaczaja czasami swoje regały jako spełniajace normę RAL. Nie jest to jednak norma, lecz powszechnie wykorzystywane oznaczenie koloru powłoki lakierniczej.

Miejscami wyznaczonymi do składowania towaru sa regały i pola odkładcze. Maksymalne piętrowanie palet na polach odkładczych wynosi trzy palety; przy uwzględnieniu rodzaju towaru moga to być dwie palety w pionie albo tylko jedna, bez piętrowania.

$\mathrm{Na}$ obszarze hali magazynowej usytuowane sa niekiedy miejsca pracy administratorów stref przyjęć/wydań czy kontrolerów jakości. Na ogół sa to biurka z komputerami, drukarkami do etykiet i szafy na dokumenty. Takie obszary mieszczą się zazwyczaj w rogu magazynu, nie jest to jednak regułą. Autorka ma za soba doświadczenie z pracy w miejscu, gdzie takie stanowiska znajdowały się na środku hali, z wózkami widłowymi poruszającymi się wokół biurka. Niezależnie od usytuowania, takie miejsca należy zabezpieczać odpowiednimi barierkami i słupkami, tych jednak nie stosuje się często. Znany jest bowiem przypadek, gdy w pewnej firmie operator wózka pomylił pedał hamulca z pedałem gazu, taranując biurko skupionego na wypełnianiu dokumentów administratora. Nikomu na szczęście nic się nie stało - pracownik zdążył odskoczyć w ostatniej chwili, a przecież takie zdarzenie mogło skończyć się tragicznie (rys. 11 i 12). 


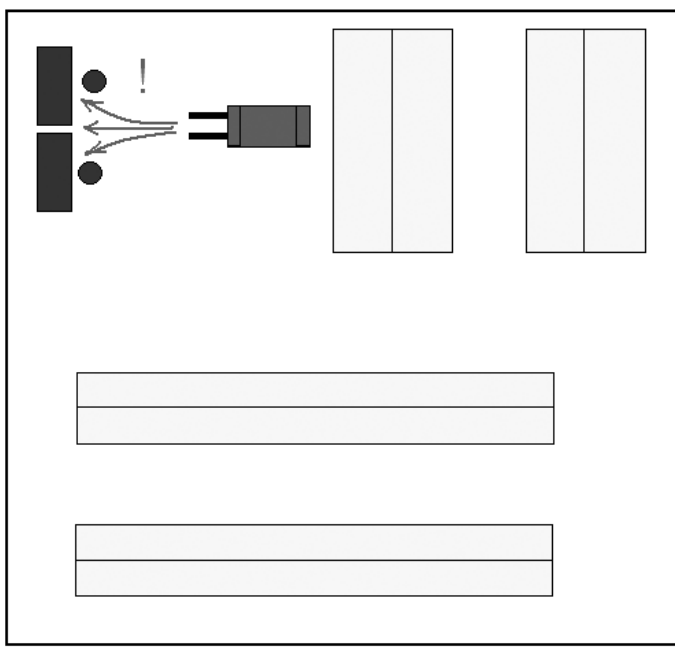

Rysunek 11. Wariant niebezpieczny usytuowania miejsc pracy administratorów magazynu

Źródło: opracowanie własne

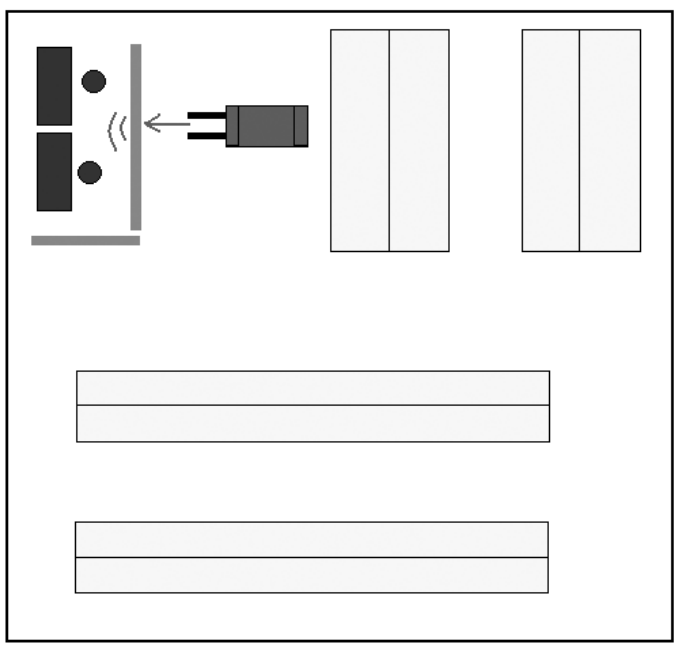

Rysunek 12. Wariant bezpieczny usytuowania miejsc pracy administratorów magazynu

Źródło: opracowanie własne

Nikt nie chciałby przecież, aby w wyniku wypadku widły wózka przebiły ścianę biura i znalazły się obok kubka z kawą na czyimś biurku. Z tego względu barierki ochronne należy stosować nawet przy zamkniętych budkach. 
Jak wspomniano wcześniej, istotne jest stosowanie barierek, słupków, wszelkiego rodzaju zabezpieczeń regałów na wypadek uderzenia wózka widłowego. Można także spotkać miejsca, gdzie dodatkowo chroni się pieszych przed potencjonalnymi zagrożeniami, oddzielając ich ciagi komunikacyjne barierkami.

Pomocnym elementem wyposażenia magazynu są lustra, które umieszcza się głównie na skrzyżowaniach, często też na rampach.

W kontekście tego, co opisano wcześniej, tj. świadomości bezpieczeństwa i organizacji hali magazynowej, warto odnieść się do licznych amatorskich nagrań wideo, na które można natrafić w Internecie, prezentujących - często spektakularne - "katastrofy budowlane" na terenie magazynu. Materiały te przedstawiaja niejednokrotnie sytuacje, w których operatorzy wózków widłowych, nie mogąc swobodnie przejechać między regałem a towarem na polu odkładczym, zahaczają o regał, który w następstwie uderzenia składa się niczym domek z kart. Gdzie w takich przypadkach popełnia się błędy? Oto propozycje odpowiedzi:

1. Zamieszanie i powszechnie panujący pośpiech sprawiaja, że często nie uznaje się granic pól odkładczych.

2. Brak drożnych ciągów komunikacyjnych skutkuje utrudnieniami w manewrowaniu wózkiem widłowym.

3. Nie dostosowuje się jakości i parametrów regałów do charakterystyki składowanego towaru. Często są one przeciążone.

4. Uszkodzenia wózkami widłowymi naruszają konstrukcję nośną regałów. Nie przeprowadza się regularnych przeglądów ich stanu.

5. Operator wózka widłowego nie ma świadomości bezpieczeństwa na terenie magazynu, nie potrafi przewidzieć skutków swoich działań.

6. Brak odbojów chroniących elementy konstrukcyjne regałów.

Bezpieczeństwo pracy w hali magazynowej nie zależy wyłącznie od nas samych, ale także od ruchu, charakteru wykonywanych prac i działań innych osób znajdujących się na tym samym terenie. Czynnikiem niebezpiecznym nie musi być wcale zawalający się regał. Wystarczy jednak, że operator wózka widłowego, zamiast zdjać paletę, nieumyślnie popchnąłby ją na druga stronę, wprost na przechodzącego tam pieszego, narażając go tym samym na poważny uszczerbek na zdrowiu, a nawet utratę życia. W magazynie wiele rzeczy jest możliwych, niewiele osób ma jednak tego pełną świadomość. 


\subsection{Składowanie zapasów}

Wiele mówi się o standardach składowania, o bezpieczeństwie w gospodarce magazynowej, a przykłady niewłaściwych zachowań sa na wyciągnięcie ręki. Na dowód tego autorka chciałaby pokazać zdjęcia z pewnego magazynu w Polsce (zdjęcie 3 i 4).

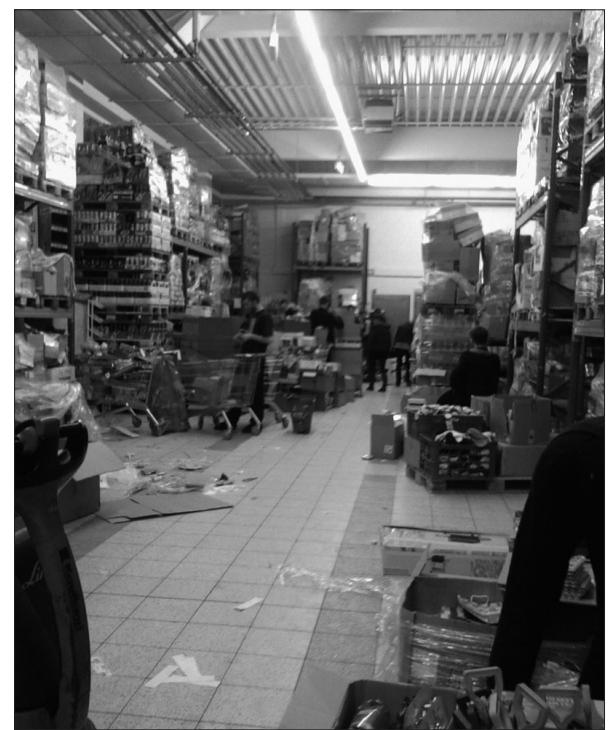

Zdjęcie 3. Jak nie składować I (fot. Monika Zajączkowska)

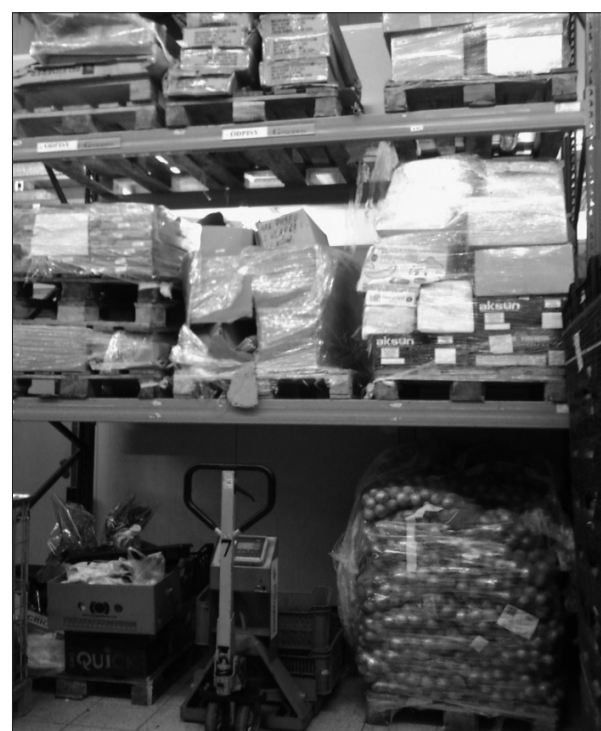

Zdjęcie 4. Jak nie składować II (fot. Monika Zajączkowska)

Jak już wcześniej wspomniano, miejscami składowania są regały i pola odkładcze, a w ramach jednej lokacji powinna znajdować się jedna paleta $z$ towarem.

Jeśli sytuacja zmusza do składowania towaru na polach odkładczych, należy wziąć pod uwagę dwa czynniki: co to jest za towar i w czym jest przechowywany. Od tego bowiem zależy, jaką ilość materiału możemy spiętrować. Maksymalna dopuszczana ilość to trzy palety, powinny to być jednak palety typu styropian albo specjalne treye. Autorka sugeruje, by na polach odkładczych nie piętrować więcej niż dwie palety, nawet $w$ treyach.

Rodzaj składowanego towaru odgrywa tutaj istotną rolę. Zgodnie z zasadami fizyki, jeżeli na dany towar naciska siła z góry, to siły działajace na towar na dole rozpieraja go we wszystkich kierunkach, czego efektem jest sytuacja, którą często widzimy - zniekształcenie (rys. 13). 


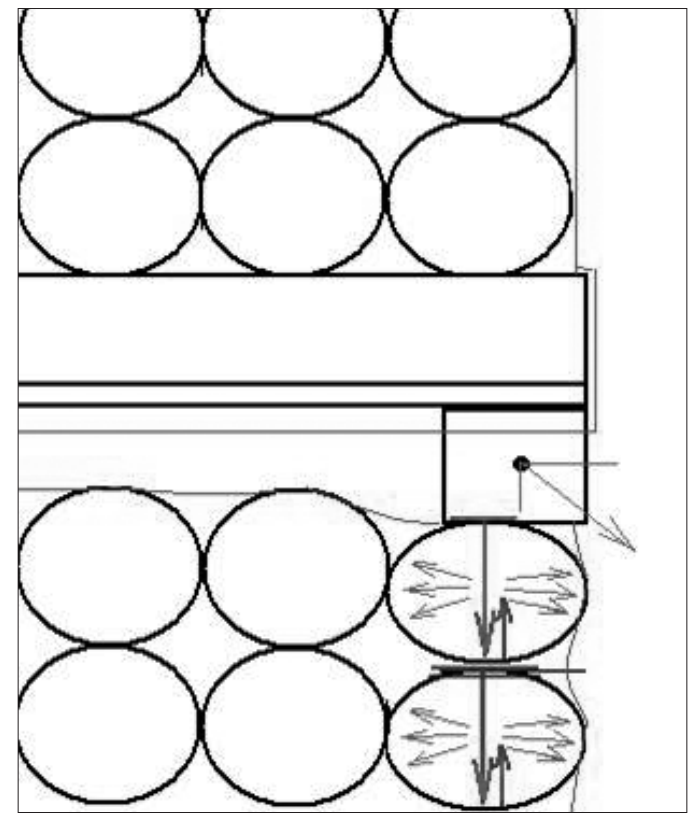

Rysunek 13. Zniekształcenie materiału sypkiego wskutek niewłaściwego piętrowania

Źródło: opracowanie własne

Towary z materiałów łatwo deformujących się, np. produkty sypkie, ulegaja powolnemu zniekształceniu, wskutek czego paleta z nimi traci pion i wszelkie piętrowane wyżej palety przewracaja się. Jeżeli mówimy o dużej ilości towaru, wszystko, co następuje potem, działa na zasadzie domina.

\subsection{Pojazdy używane w gospodarce magazynowej}

Pojazdy używane w gospodarce magazynowej maja znaczący wpływ na bezpieczeństwo ludzi i towaru. W tej części należy wspomnieć o przewożeniu towaru i jego znaczeniu dla bezpieczeństwa. Zasada dotycząca transportowania mówi, że towar przewożony na widłach powinien sięgać do wysokości brody kierującego pojazdem, tak aby mógł on bezpiecznie nim kierować. Jeśli operator wózka ma zamiar przewieźć więcej niż jedną paletę naraz, należy zastosować przedłużki na widły.

Często bywa jednak tak, że nie tylko jeden taki "słupek" jest przewożony, ale także na przedłużkach wideł operator transportuje jedno- 
cześnie dwukrotnie większą liczbę palet. Jak w takich przypadkach kierowca widzi to, co ma przed sobą? Odpowiedź: patrzy przez szpary w paletach. Nie należy także przewozić towaru z widłami uniesionymi do góry. Widły powinny być możliwie jak najbliżej podłoża.

Kolejna kwestią, o której należałoby wspomnieć, jest środek ciężkości wózka widłowego. Reguła trójkąta stabilności mówi, że niezaładowany wózek widłowy ma środek ciężkości w środku trójkąta, za przednimi kołami, załadowany zaś i z maksymalnie podniesionym masztem zmienia swój środek ciężkości do granicy boku trójkąta. Jeśli dopuszczalna masa towaru na widłach zostanie przekroczona, pojazd straci równowagę i przewróci się.

Przygotowując się do napisania tego rozdziału, autorka natrafiła na interesująca stronę internetowa japońskiego stowarzyszenia JICOSH (Japan International Center for Occupational Safety and Health). Można na niej zapoznać się m.in. ze studiami przypadków dotyczącymi przykładowych negatywnych zachowań z udziałem wózków widłowych.

\subsection{Czas jako czynnik wpływający na bezpieczeństwo ludzi i zapasów}

Jednym z czynników, niewątpliwie wpływającym na bezpieczeństwo w gospodarce magazynowej, jest permanentny brak czasu. Zadania sa "na wczoraj”, wszyscy wokół krzycza "szybciej, szybciej”. Operatorzy wózków nie nadążaja zjeść posiłku, ponieważ w tym czasie zalewani sa dziesiątkami kolejnych zadań na terminalu. Uznaja, że lepiej jest więc ukryć kanapkę w barierce na hali magazynowej i podjadać przy okazji przejazdu nieopodal niż iść na 15-minutowa przerwę.

Ustanawiane przez firmy procedury (jeśli takowe w ogóle istnieja) są często nieprzestrzegane, ponieważ nie ma czasu na wykonywanie zadań zgodnie z nimi, co z kolei wydłużyłoby czas poświęcany na realizację tego zadania (zasada "błędnego koła”). Dlatego zalaminowane cyfry kontrolne wożone w kieszeniach operatorów wózków są nierzadko na porządku dziennym.

Jeżeli wózek ulegnie awarii, należy go w jakikolwiek sposób przywrócić do "życia”. Jak to zrobić, zależy niejednokrotnie od zdolności technicznych i wyobraźni operatora pojazdu. Bywa, że wózki widłowe jeżdżą dzięki bardzo zmyślnym wynalazkom, których nie powstydziłby się MacGyver we własnej osobie. To patologiczne przykłady wynikające z tego, że ludzie nie "wyrabiaja się" w realizacji powierzonych za- 
dań. Jest ich za dużo przy zbyt małej obsadzie pracowniczej. Są cięcia kosztów. Na szczęście jednak jest wiele firm, w których przestrzega się ustalonych procedur, całość zaś funkcjonuje jako zdrowy organizm.

Jakie mamy inne skutki uboczne braku czasu i nadmiaru zadań? Obsługujący wózki przewożą ogromne ilości towaru. Czy widza, kto lub co znajduje się przed nimi? Niejednokrotnie na tyle, na ile pozwoli im szczelina w palecie. $Z$ pojazdów zdejmowane sa blokady prędkości, a wszystko po to, by było szybciej, by zrobić więcej.

Abstrahując od braku stosownych umiejętności czy doświadczenia, operatorzy pracuja pod tak wielką presją czasu i nałożonych nań zadań, są tak zmęczeni, że popełniają błędy, zdarza im się wykonać ruch nieprzemyślany, automatyczny. $Z$ tego powodu:

- spadaja palety z materiałem,

- mylony jest pedał hamulca z pedałem gazu albo inne klawisze na pulpicie maszyny,

- uszkadza się elementy stałe na terenie magazynu,

- naraża się zdrowie i życie współpracowników,

- pojazd spada z rampy,

- doprowadza się do utraty środka ciężkości wózka widłowego,

- popełnia się szereg innych błędów, np. operacyjnych (załadowanie samochodu niewłaściwym towarem).

\subsection{Podsumowanie}

Ugruntowane wśród przedsiębiorców przekonanie o BHP jako hamulcu sprawnego działania firmy od lat wydaje dorodny plon. Wypadki przy pracy, uszkodzony sprzęt, zniszczony towar - lista nieprawidłowości od strony bezpieczeństwa pracy w wielu magazynach jest długa. Jak tu jednak realizować wysyłki "na wczoraj”, kiedy przepisy nakazuja przemieszczać się wyłącznie wyznaczonymi ciągami komunikacyjnymi? Dlaczego ambitne plany dystrybucyjne niweluja właśnie ograniczenia prędkości jazdy wózków widłowych? I wreszcie: dlaczego, gdy z powodu zbyt krótkiej drabiny ktoś podniósł na widłach kolegę magazyniera, by ten mógł pobrać towar z regału, nikt nie robi mu karczemnej awantury? Stawianie tego typu pytań wynika głównie z podkreślanych w niniejszym rozdziale: niewiedzy w zakresie zarządzania i braku świadomości zagrożeń czyhających na pracowników.

Takie zachowania mogłyby sugerować konieczność wdrożenia „pracy u podstaw". Nic bardziej mylnego, ponieważ - jak słusznie zauważy- 
ła wcześniej autorka - „przykład idzie z góry”. Gdyby bowiem dyrektor generalny, wizytując magazyn, skalał swój garnitur od Armaniego kamizelką ochronna, z pewnością otworzyłoby to niektórym oczy na fakt, iż dbanie o bezpieczeństwo $\mathrm{w}$ miejscu pracy $\mathrm{i}$ terminowa realizacja powierzonych zadań są tematami, które wzajemnie się nie wykluczaja. Jaka jest przyczyna takiego stanu rzeczy? Bez watpienia jest nia nierzadka wśród kadry kierowniczej niekompetencja oraz brak stosownej wiedzy i umiejętności. Czy jednak nie jest temu winny także „BHP-owiec", który niejednokrotnie jest nim tylko z nazwy, a organizowane przez niego szkolenia sprowadzają się do "podpisu na ostatniej stronie"? A może należałoby rozszerzyć perspektywę analizy problemu i dowiedzieć się, z czego wynika nagminne lekceważenie przepisów prawnych? Podobnych hipotez można by postawić znacznie więcej. Odpowiedź na przynajmniej część z nich zaowocowałaby zamknięciem magazynów, w których obuwie ochronne ma z safety niewiele wspólnego, a cięcia kosztów dotykaja tej "najmniej ważnej" sfery działalności przedsiębiorstwa, jaką jest BHP.

Jako podsumowanie tego rozdziału należy wskazać - niejako w opozycji do zaprezentowanych wcześniej przykładów negatywnych zachowań - firmy, które rozumieją symbiozę pomiędzy gospodarką magazynowa a bezpieczeństwem pracy. Tam bowiem wdrożono takie systemy zarządzania, które umożliwiają efektywną realizację zadań przy jednoczesnym zachowaniu zasad BHP. W tych przedsiębiorstwach kadra zarządzająca jest świadoma, że koszt regularnych przegląów elementów nośnych regałów czy instalacji pasów bezpieczeństwa w wózkach widłowych jest niczym w porównaniu z kosztami wypadku przy pracy. Takie zdarzenie pociagga bowiem za soba nie tylko koszt zniszczonego sprzętu i towaru - to również utrata zysków, wydatki związane z obsługa prawna, odszkodowania. W takich przypadkach zaniedbanie kilkutysięcznej inwestycji może przynieść dziesiątki lub nawet setki tysięcy złotych strat. 